\title{
Studi Kasus: Penanganan Korneal Squestrum pada Kucing Domestic Short Hair
}

\section{Case Report: Corneal Sequestrum Treatment in Domestic Short Hair Cat}

\author{
Pambudi, G. R1, Anwar, R. N1, Rini, W. S1, Aeka, A² \\ 1Pendidikan Profesi Dokter Hewan, Fakultas Kedokteran Hewan Universitas \\ Brawijaya \\ ${ }^{2}$ Fakultas Kedokteran Hewan, Universitas Brawijaya \\ *email:
}

\begin{abstract}
ABSTRAK
Korneal squestrum merupakan suatu keadaan yang terjadi pada kornea yang telah mengalami kornea ulser dalam kurun waktu yang panjang/kronis. Kornea merupakan struktur pada mata bagian depan yang memiliki warna transparan dan tersusun atas outer epitelium, middle stroma dan inner endothelium. Pemeriksaan dasar yang dilakukan pada pasien adalah menace, dazzle dan pupillary reflex. Sedangkan pemeriksaan penunjang yang dilakukan adalah schiemer tear test dan fluorescein test. Hasil pemeriksaan dasar menunjukkan hasil yang positif tanpa adanya gangguan penglihatan. Sedangkan hasil fluorescein test menunjukkan hasil positif kornea ulser dengan adanya pendaran warna hijau. Terapi dilakukan dengan memberikan antibiotik (cendo genta 0,3\%) s.6.d.d selama 2 minggu. Respon possitif ditunjukkan oleh pasien dengan hasil fluorescein test negatif pasca 2 minggu pengobatan. Akan tetapi, masih terdapat jaringan-jaringan berwarna putih kecoklatan yang menutupi permukaan korneal. Terapi dilanjutkan dengan memberikan cendoxitrol s.2.d.d selama 2 minggu. Respon yang diberikan pasien kurang baik, jaringan berubah menjadi kecoklatan atau disebut dengan korneal squestrum.

Kata Kunci : Kornea ulser, Korneal squestrum
\end{abstract}

\section{ABSTRACT}

Corneal squestrum is a pathological condition of cornea which have been affected by prolonged cornea ulcer/chronic cornea ulcer. Cornea is clear structure 
of the eye that located at the cranial area and contain some layer such as outer epitelium, middle stroma and inner endothelium. Basic eye examinations have been conducted to the patient were menace, dazzle and pupillary reflex. Supportive eye examination have been conducted to the patient were schiemer tear test and fluorescein test. The result of basic eye examination showed a positive result, which mean it still had a good function. Fluorescein test showed a positive result, showed a green pigmented at the cornea presumed as cornea ulcer. Antibiotic therapy was given by cendogenta 0,3\% s.6.d.d. for two weeks. Positive respond was showed by the patient by a negative result of fluorescein test post 2 weeks of treatment. Some tissue with brownish colour were still remain at the surface of the cornea. The therapy by cendoxitrol was given s.2.d.d. for 2 weeks. The respond was negative. The brownish tissue still remains, and this kind of condition called with corneal squestrum.

Key Word : Cornea ulcer, Corneal squestrum

\section{PENDAHULUAN}

Kucing Domestic Short Hair (DSH) merupakan kucing ras yang memiliki bulu yang pendek. Kucing ras ini adalah jenis kucing berbulu pendek diluar dari jenis ras kucing yang ada. Tidak hanya di Indonesia, kucing DSH ditemukan di hampir setiap negara yang ada di dunia, baik di negara dengan iklim tropis maupun iklim sub tropis. Kucing ras DSH memiliki nilai populasi yang paling tinggi di dunia apabila dibandingkan dengan kucing dengan jenis ras lainnya. Kucing DSH muncul akibat adanya kawin silang yang tidak disengaja/tidak diinginkan, kawin silang terjadi antara dua ras kucing yang berbeda dengan hasil anakan yang tidak termasuk dari ras manapun. Kucing ras ini banyak ditemukan sebagai kucing liar (stray cat) di Indonesia (Hilsspet, 2020).

Kornea ulser biasanya hanya terjadi bila mekanisme pertahanan okular mengalami gangguan atau kerusakan. Namun beberapa bakteri dapat berpenetrasi pada epitel kornea normal, seperti $N$. gonorrhoeae, $N$. meningitidis, C. diphteriae, dan $H$. influenza (Kanski, 2007). Pada tingkat kejadian kronis, kornea ulser dapat menimbulkan korneal squestrum dengan adanya perubahan jaringan menjadi gelap kecoklatan (Gelatt, 2014).

\section{ANAMNESA}

Seekor kucing berjenis kelamin jantan dengan usia \pm 4 bulan dengan berat badan $0,7 \mathrm{~kg}$ ditemukan mengalami gejala berupa mata kiri 
kotor dan tertutup di daerah Belimbing Malang.

\section{TEMUAN KLINIS}

Temuan klinis yang ditemukan pada kucing Jono diantaranya adalah mata sinister menutup dan ditemukan adanya discharge berwarna putih kekuningan dengan kondisi tubuh 2/5 dan pada pemeriksaan fisik lainnya tidak ditemukan adanya kelainan.

\section{PEMERIKSAAN}

Uji reflek menace dilakukan untuk melihat reflek mata terhadap pergerakan objek yang mendekati mata secara tiba-tiba, terutama untuk mengamatai adanya gangguan pada nervus opticus dan nerous facialis. Reflek dari uji menace dapat berupa kedipan mata atau memalingkan kepala menjauhi stimulus (Tuner, 2008). Hasil uji menunjukkan hasil posotif.

Sementara itu pemeriksaan refleks Dazzle adalah untuk mengetahui refleks subcortical yang merespon cahaya terang yang masuk kemata secara cepat. Pemeriksaan ini ditujukan untuk mengetahui kondisi nervus cranial II (nervusoptikus), rostral colliculus, supraoptic nuclei dari hypothalamus dan cranial nervus VII (menginervasi orbicularis oculli) berperan pada pemeriksaan refleks dazzle. Refleks dazzle dilakukan untuk mengevaluasi fungsi retina dan nervus opticus (Turner, 2008). Hasil uji menujukkan hasil uji positif.

$$
\text { Pada pemeriksaan ini }
$$
ditujukan untuk mengetahui adanya respon pupil yaitu midriasis dan miosis. Pemeriksaan pupillary light reflex (PLR) dapat dioptimalkan pada ruangan pemeriksaan yang gelap. Pemeriksaan pupillary light reflex (PLR) dapat dilakukan dengan dua metode yaitu direct PLR dan konsensual PLR. Direct PLR digunakan untuk melihat reflex pupil pada salah satu mata, sementara itu konsensual PLR untuk melihat reflex kedua pupil (mata kanan dan mata kiri)karena kedua reflex pupil akan merespon sama antara mata kanan dengan mata kiri (Turner, 2008). Pada pemeriksaan ini pasien pada kedua pupil mata pasien masih dapat merespon dengan baik.

Schimer tear test atau STT adalah sebuah tes yang digunakan mengukur produksi air mata. Tes air mata ini aman dan tidak memerlukan anestesi. Sebuah strip uji khusus yang menyerupai kertas lakmus ditempatkan ke kelopak mata, untuk membuat kontak dengan kornea. Setelah strip ditempelkan pada mata kucing, mata tersebut ditutup dan dibiarkan selama 1 menit. Kemudian dilihat hasilnya yang ditentukan oleh seberapa banyak warna yang terlihat pada kertas strip (Turner, 2008). Hasil 
uji adalah 18, dengan nilai rentang normal 15-20 (Turner, 2008).

Fluorescein test atau disebut FT merupakan suatu tes yang digunakan untuk mendeteksi dan mengetahui adanya perlukaan atau abrasi pada permukaan kornea. Aplikasi dilakukan dengan meneteskan FT pada mata atau FT strip yang telah dibasahi terlebih dahulu dengan $\mathrm{Nacl}$ fisiologis dan ditempelkan pada mata. Larutan FT yang berwarna orange akan mengalir dan menyebar ke seluruh permukaan mata. Mata kemudian dibilas dengan larutan saline untuk membersihkan sisa warna flourescein. Pewarna FT menempel hanya pada area yang terabrasi dan dapat diamati dengan opthalmoscope yang diberi pencahayaan sinar ultra violet (Croix, 2010). FT yang dilakukan pada kucing Jono adalah sebanyak 3 kali yaitu pada saat pemeriksaan pertama, pemeriksaan kedua dilakukan pada saat 2 minggu post terapi dan pemeriksaan ketiga dilakukan pada 3 minggu post terapi. Pada pemeriksaan pertama FT menunjukkan adanya garis warna hijau yang teramati sehingga diindikasikan kucing jono mengalami kornea ulser. Sedangkan pada pemeriksaan kedua dan ketiga tidak menunjukkan adanya warna hijau yang mengindikasikan ulser pada kornea telah mengalami perbaikan.

\section{DIAGNOSA}

Hasil

pemeriksaan menujukkan pasien mengalami kornea ulser.

\section{TERAPI}

Pengobatan terhadap kornea ulser dilakukan dengan cara memberikan antibiotik (cendogenta 0,3\%). Pengobatan dilakukan dengan memberikan antibiotik sebanyak 2 tetes pada mata yang mengalami ulser, dilakukan sebanyak 6 kali selama satu hari. Pengobatan ini dilakukan selama 2 minggu untuk kemudian dilakukan evaluasi kembali dengan menggunakan FT tes. Hasil evaluasi menujukkan hasil negatif.

Kondisi mata menujukkan masih adanya jaringan berwarna putih kecoklatan pada bagian permukaan kornea. Pengobatan dilanjutkan dengan menggunakan obat antitinflamasi cendoxitrol sebanyak 1 tetes dan dilakukan sebanyak 2 kali selama 2 minggu. Hasil tidak menujukkan respon positif. Jaringan yang terdapat pada permukaan kornea mengalami perubahan warna menjadi lebih kecoklatan. Keadaan ini disebut dengan korneal squestrum.

\section{PEMBAHASAN}

Pasien mengalami kelainan yang ditemui pada mata diantaranya adalah mata kiri yang terlihat kotor 
dan terlihat adanya luka pada mata tersebut. Beberapa langkah dalam melakukan pemeriksaan pada kasus penyakit di mata dimulai pada pemeriksaan sinyalemen dan anamnesa. Pemeriksaan mata pada pasien diawali dengan pemeriksaan dasar dengan memperhatikan pemeriksaan menace response. Pemeriksaan ini bertujuan untuk mengetahui adanya respon neurologis dari hewan apabila diberikan gerakan mendadak yang membuat hewan akan berkedip (Turner, 2008). Pemeriksaan tersebut menunjukkan hasil bahwa pasien masih memiliki respon untuk berkedip pada mata kiri setelah dilakukan pemeriksaan dengan memberikan gerakan mendadak. Melihat respon dari pasien yang berkedip dapat diketahui bahwa kondisi neurologis dari pasien terutama nervus optikus dan nervus cranialis II masih baik selain itu pada kondisi berkedip juga menunjukkan kondisi nervus facialis dan nervus cranialis VII masih baik. Pemeriksaan selanjutnya adalah dengan melakukan pemeriksaan dazzle dengan menggunakan pen torch tujuan dari pemeriksaan ini adalah untuk mengetahui kondisi dari retina (Turner, 2008). Pemeriksaan terhadap kondisi glandula lakrimalis dari pasien juga menunjukkan hasil bahwa kondisi glandula lakrimalis pasien masih menghasilkan air mata dengan (C)2020. Pambudi et al. Open access under CC BY - SA license, doi: 10.20473/mkh.v31i2.2020.85-96 Received: 06-07-2020, Accepted: 09-09-2020, Published online: 29-09-2020 Available at https://e-journal.unair.ac.id/MKH/index baik yaitu dengan hasil sekitar 19 $\mathrm{mm} / \mathrm{min}$. Pemeriksaan fluorescein test pada pasien menunjukkan hasil bahwa terdapat luka pada kornea (gambar 1).

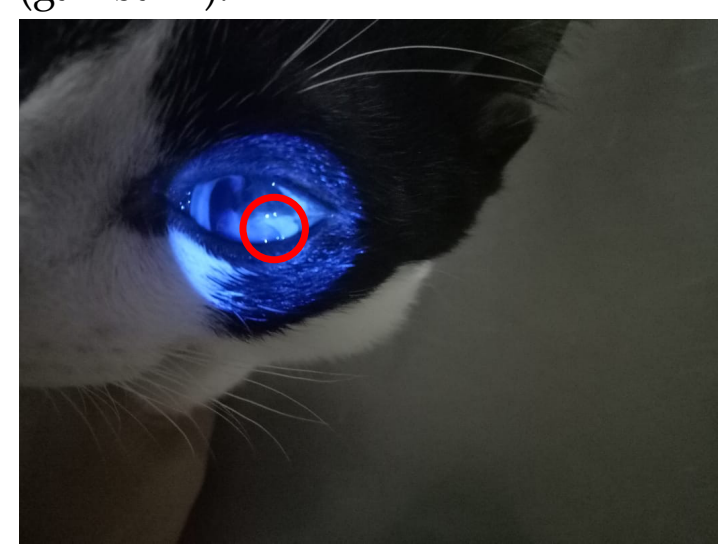

Gambar 1. Hasil pemeriksaan

fluorescein test pada mata kiri sebelum dilakukan terapi

Diagnosa terhadap kasus tersebut adalah penyakit korneal sequestrum yang diawali dari kasus kornea ulser yang berkepanjangan atau kronis dan tidak kunjung sembuh. Kornea merupakan lapisan transparan yang terdapat pada bagian depan mata yang tersusun atas outer epitelium, middle stroma dan inner endothelium. Sementara itu diantara kedua stroma dan endothelium terdapat membrane descemet. Tebal kornea berkisar antara 0,45-0,55 mm (Turner, 2008). Struktur anatomi dari 
kornea terdapat pada gambar seperti pada gambar 2 .

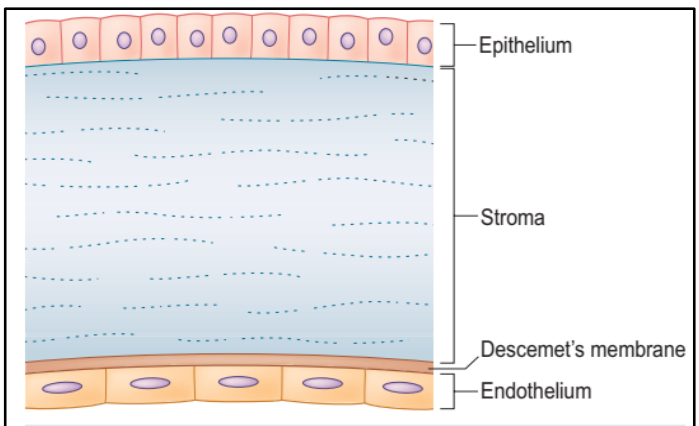

Gambar 2. Struktur bagian dalam kornea (Turner, 2008).

Kornea atau selaput bening mata merupakan jaringan transparan yang menutup bola mata sebelah depan. Kornea berfungsi sebagai membran pelindung dan media refraksi

yang dilalui oleh berkas cahaya saat menuju retina. Kornea merupakan jaringan transparan yang menutupi bola mata depan yang terdiri dari lima lapisan, yaitu epitel, membrane bowman, jaringan stroma, membran descemet dan endotel. Korneal ulser adalah penyakit yang mana kornea proses inflamasi dan terjadi diskontinuitas epitel kornea. Gejala ulkus kornea secara umum berupa nyeri, turunnya tajam penglihatan, mata merah, fotofobia, dan sekret purulen atau mukopurulen. Sering disertai dengan hipopion, suatu penumpukan sel inflamasi yang terlihat sebagai lapisan sekret keruh di bagian bawah kamera okuli anterior
(Douglas, 2015). Hipopion pada ulkus kornea bakterialis bersifat steril kecuali terdapat ruptur pada membran Descemet (Biswell, 2011). Ulkus kornea biasanya hanya terjadi bila mekanisme pertahanan okular mengalami gangguan atau kerusakan. Namun beberapa bakteri dapat berpenetrasi pada epitel kornea normal, seperti $N$. gonorrhoeae, $N$. meningitidis, $C$. diphteriae, dan $H$. influenza (Kanski, 2007).

Korneal sequestrum merupakan salah satu penyakit yang terdapat pada bagian kornea mata yang ditandai dengan adanya perubahan warna kornea menjadi gelap diikuti dengan adanya perlukaan (ulser) yang tidak dapat sembuh (Gelatt, 2014). Korneal sequestrum jarang terjadi pada anjing, namun sering sekali terjadi pada kucing. Korneal sequestrum disebabkan oleh beberapa sebab namun yang paling sering adalah disebabkan karena luka cakaran akibat bertengkar. Korneal sequestrum diikuti dengan adanya jaringan nekrosis stroma yang akibatkan karena kesembuhan luka yang lama yang diawali dari ulser pada kornea.

Diagnosa pada kasus penyakit korneal sequestrum dilakukan melalui beberapa tahapan diantaranya adalah ditemukan adanya abnormalitas dari pemeriksaan 
terhadap mata terutama pada kornea. Pada pasien ditemukan adanya abnormalitas yaitu munculnya luka ulser pada kornea setelah dilakukan pemeriksaan fluorescein test (gambar 1).

Pengobatan dilanjutkan dengan melakukan memberikan terapi cendo genta 0,3\% dengan terapi sebanyak s.6.d.d untuk pengobatan terhadap ulser pada kornea, namun setelah pemberian selama 2 minggu (14 hari) setelah dilakukan pemeriksaan ulser pada kornea masih ada. Pasien juga sudah diberikan elizabeth collar untuk mencegah pasien menggaruh area luka. Setelah diberikan terapi tersebut luka masih ada dan setelah dilakukan pemeriksaan fluorescein test yang kedua masih terdapat luka pada kornea pasien. Pengobatan dilanjutkan dengan menggunakan terapi cendo genta $0,3 \%$ dengan dosis s.8.d.d namun setelah selama 2 minggu (14 hari) terapi dan luka sudah sembuh (gambar 3).

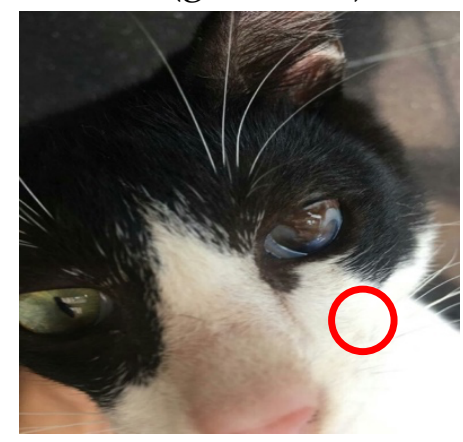

Gambar 3. Hasil pemeriksaan

fluorescein test pada mata kiri sebelum dilakukan terapi

Pengobatan umumnya untuk ulkus kornea adalah dengan sikloplegik,

antibiotika. Terapi yang dilakukan terhadap pasien dilakukan dengan cara menyembuhkan ulser pada kornea dengan kandungan antibiotik dan antiinflamasi. Pengobatan pada ulkus kornea bertujuan menghalangi hidupnya bakteri dengan antibiotika, dan mengurangi reaksi radang dengan steroid. Terapi juga diberikan cendoxitrol, obat tersebut merupakan obat tetes mata dengan kandung antiflamasi steroid berupa dexamethasone. Penggunaan obatobatan corticosteroid dalam penyakit kornea ulser harus memperhatikan kesembuhan dari luka dan hilangnya infeksi dari kornea itu sendiri. Pemberian corticosteroid dapat menyebabkan mengecilnya jaringan stroma dari kornea, neovascularisasi, dan berkurangnya ukuran jaringan parut yang disebabkan karena proses inflamasi dan respon imun dari infeksi dari bakteri (Kardena, 2020). Corticosteroid akan menyebabkan menurunnya rasa sakit pada mata. Pada fase akut dari infeksi toksin dari bakteri akan berinteraksi dari jaringan epithelial yang luka sehingga menyebabkan reaksi imun yang mengakibatkan terlepasnya sitokin, 
growth factors, kolagen yang menyebabkan terjadinya apoptosis dan destruksi jaringan kolagen (Dana et al., 2000). Setelah infeksi pada mata sembuh, maka keratosit akan berubah menjadi fibroblast yang aktif sehingga akan terbentuk kolagen dan matriks ekstraselular yang berbentuk irregular sehingga kornea menjadi keruh dan terlihat adanya jaringan yang menebal (Lim et al., 2003). Pemberian obat corticosteroid akan menyebabkan penurunan aktivitas kemotaksis dari neutrophil sehingga dapat menyebabkan pembentukan kolagen menurun (Chung et al., 1998). Oleh sebab itu, pemberian obat corticosteroid sebaiknya diberikan pada saat luka di kornea sudah sembuh sehingga tidak menghambat respon inflamasi dan imunologis (ts et al., 1990). Pengobatan yang dapat dilakukan untuk kasus penyakit korneal sequestrum adalah melakukan tindakan operasi (Turner, 2008).

\section{KESIMPULAN}

Pasien mengalami penyakit korneal ulser yang berkepanjangan dan kronis sehingga menimbulkan terbentuknya jaringan luka akibat proliferasi dari sel fibroblast. Diagnosa berubah dari awal yaitu korneal ulser menjadi korneal sequestrum sehingga perlu adanya tindakan operasi untuk kesembuhan pasien.

\section{DAFTAR PUSTAKA}

Biswell, R., Vaughan, D.G., Asbury, T. 2011. Ophtalmology Umum Ed. 14. Jakarta. EGC

Chung, J., Kang, Y., Kim, H. J. 1998. Effect of $0.1 \%$ dexamethasone on epithelial healing in experimental corneal alkali wounds: morphological changes during the repair process. Graefes Arch Clin Exp Ophthalmol. 236(7):537-545.

Dana, M. R., Qian, Y., Hamrah, P. 2000. Twenty-five-year panorama of corneal immunology: emerging concepts in the immunopathogenesis of microbial keratitis, peripheral ulcerative keratitis, and corneal transplant rejection. Cornea.19(5):625-643.

Douglas, W.E. 2015. Clinical Atlas of Canine and Feline Ophtalmic Disease. Iowa : Blackwell Willey Publishing

Gelatt, K.N., and Gelatt, J.P. 2011. Veterinary Ophthalmic Surgery. Elsevier ltd.

Hilsspet. 2020. Domestic Short Hair Cat Breed : Personality and Information | Hill's Pet. 
https:/ / www.hillspet.com/cat -care/cat-breeds/domesticshorthair [Diakses pada 30 Oktober 2020]

Kanski, J and Bowling. 2007. Clinical Ophthalmology. Elsevier.

Kardena, I.M. 2020. Patologi Veteriner Sistem Mata dan Telinga. Universitas Udayana

Lim, M., Goldstein, M. H., Tuli, S, et al. 2003. Growth factor, cytokine and protease interactions during corneal wound healing. Ocul Surf. 1(2):53-65.

Turner, S. M. 2008. Small Animal Ophtamology. Elsevier 